\title{
First insights into the migration route and migratory connectivity of the Paddyfield Warbler using geolocator tagging and stable isotope analysis
}

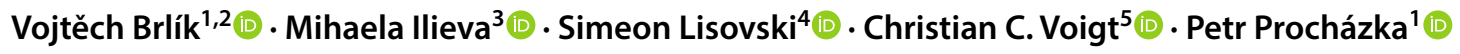

Received: 4 April 2018 / Accepted: 25 April 2018 / Published online: 18 May 2018

(c) Dt. Ornithologen-Gesellschaft e.V. 2018

\begin{abstract}
The Paddyfield Warbler Acrocephalus agricola has recently expanded its breeding range westwards to the western coast of the Black Sea. Although its non-breeding range is known (southern Iran to northern Myanmar), current knowledge on how individual birds migrate and how their routes evolve alongside range expansion processes is very limited. Data from one geolocator deployed on a Paddyfield Warbler at a recently established breeding site in Bulgaria show that this individual retraced the recent range expansion and followed a rather conservative route instead of migrating directly to India. An additional stable hydrogen $\left(\delta^{2} \mathrm{H}\right)$ analysis of feathers from 25 individual breeding birds in Bulgaria that had been grown during their stay in the non-breeding grounds indicated a low degree of migratory connectivity at the non-breeding grounds. Our results provide a first insight into the migration pattern of the Paddyfield Warbler and should stimulate further research on the use of the understudied Indo-European flyway by this species.
\end{abstract}

Keywords Bird migration $\cdot$ Indo-European flyway $\cdot$ Light-level geolocation $\cdot$ Migration direction $\cdot \delta^{2} \mathrm{H}$

\section{Zusammenfassung}

Geolokatoren und stabile Isotopenanalyse liefern erste Erkenntnisse über Zugwege und räumlichen Konnektivität vom Feldrohrsänger

Die geographischen Grenzen des Brutgebiets des Feldrohrsängers (Acrocephalus agricola) haben sich in letzter Zeit in Richtung Westen, bis hin zur Küste des Schwarzen Meeres, vergrößert. Obwohl es bekannt, wo sich die Art außerhalb der Brutzeit aufhält (südlicher Iran bis nördliches Myanmar), kennen wir weder die individuellen Zugstrecken noch die genauen Mechanismen, wie sich die Zustrecken in Gebieten der geographischen Artausbreitung evolvieren, kaum. Die Daten eines Geolokators, welcher die Zugwege eines einzelnen Individuums aus einem kürzlich in Bulgarien neu besiedeltem Brutgebiet aufzeichnete, zeigen, dass dieses Individuum dem Ausbreitungsmuster des Brutgebiets folgte und somit der Zugweg eher ein Umweg als eine direkter Flug ins Wintergebiet nach Indien darstellt. Eine zusätzliche Analyse von Wasserstoffisotopen aus Federn welche im Wintergebiet gemausert und im Brutgebiet in Bulgarien gesammelt wurden weist auf eine niedrige räumliche Konnektivität zwischen Brut- und Wintergebiet hin. Diese Ergebnisse liefern erste Erkenntnisse über das Zugverhalten von Feldrohrsängern und sollten das Interesse an wissenschaftlichen Projekten über diese Arten und deren noch wenig untersuchten Indo-European Zugweg stimulieren.

Communicated by N. Chernetsov.

Electronic supplementary material The online version of this article (https://doi.org/10.1007/s10336-018-1557-9) contains supplementary material, which is available to authorized users.

Vojtěch Brlík

vojtech.brlik@gmail.com

Extended author information available on the last page of the article

\section{Introduction}

Range expansions have the potential to change migration routes in newly established breeding populations (Sutherland 1998). While some populations seem to adjust to the new flyways and distances (e.g. Berthold et al. 1992), others use ancestral migration routes along the paths of expansions (e.g. Bairlein et al. 2012). 
The Paddyfield Warbler Acrocephalus agricola, which has a core breeding area in Central Asia, has recently expanded into eastern Europe (Gavrilenko 1954) and currently has established breeding populations as far west as the coast of the Black Sea in Bulgaria (Kennerley and Pearson 2010). The non-breeding range of the species is restricted to the area extending from southern Iran to northern Myanmar (Kennerley and Pearson 2010). However, almost no information is available on the migration strategies of Paddyfield Warblers flying along the Indo-European flyway and how different breeding populations are distributed across the nonbreeding area.

The major aim of the study presented here was to collect individual migration tracks using light-level geolocation datalogger to test the hypothesis that the westernmost Paddyfield Warbler breeding population follows the expansion path, as has been suggested by previous orientation experiments (Zehtindjiev et al. 2010). We also sampled feathers from individuals on their Bulgarian breeding sites that were molted during the non-breeding period and subjected these to stable hydrogen $\left(\delta^{2} \mathrm{H}\right)$ isotope analysis with the aim to obtain insights into the variation of non-breeding sites among individuals of this particular breeding population.

\section{Methods}

We captured and marked Paddyfield Warblers staying at the Black Sea coast in Bulgaria (Durankulak Lake: $43^{\circ} 41^{\prime} \mathrm{N}$, $28^{\circ} 33^{\prime} \mathrm{E}$; Shablenska Tuzla Lake: $43^{\circ} 33^{\prime} \mathrm{N}, 28^{\circ} 35^{\prime} \mathrm{E}$; Fig. 1) and deployed light-level geolocators using backpack harness on 34 adults during 2014 and 2015. For the stable isotope analysis, we sampled 25 innermost primaries at the study sites in 2015 and another one upon geolocator retrieval in 2016. Details on marking, tagging and its effect on the birds as well as the handling of samples are provided in Electronic Supplementary Material (ESM) 1.

We used the R package FLightR to estimate geographic locations based on the light recordings (Rakhimberdiev et al. 2017). The method uses a template fit to estimate a spatial likelihood surface for each twilight period and applies a particle filter to sample from these likelihoods and to derive a posterior distribution describing the likeliest path along with credible intervals. Detailed information on the twilight calculation and calibration is given in ESM 1.

For the stable isotope analysis, we prepared a subsample $(0.272 \pm 0.007 \mathrm{mg}$ [mean \pm standard deviation] $)$ of equilibrated and cleaned feather samples, and after combustion we calculated the $\delta^{2} \mathrm{H}$ ratios between the samples and the keratin standard [for more details see Popa-Lisseanu et al. (2012)]. The internal laboratory keratin standards were scaled to those established in Saskatoon in order to use the
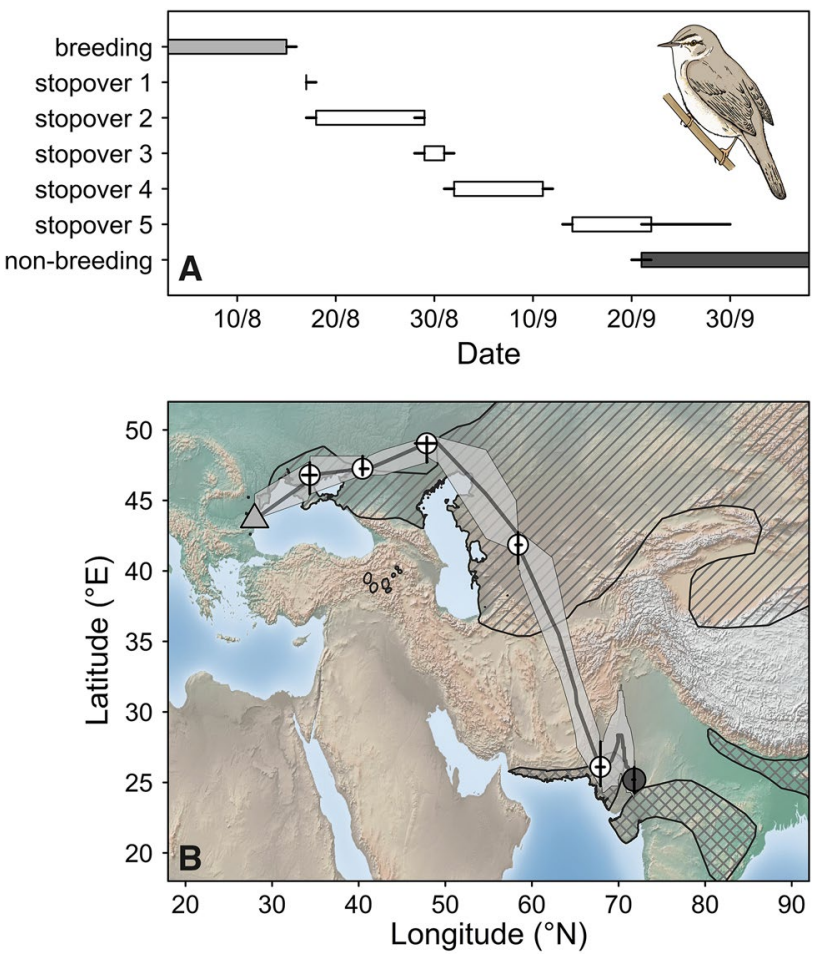

Fig. 1 a Timing of the post-breeding migration of a geolocatortracked Paddyfield Warbler (Acrocephalus agricola). Bars represent the stationary periods defined by the median time of arrival and median time of departure. Lines represent the interquartile range (IQR) of the arrival and departure times, respectively. b Map showing the location of stationary periods during the post-breeding migration (white) and the non-breeding grounds (dark gray). The triangle indicates the breeding ground of the tracked bird (light gray). The lines within each circle denoting the location of stationary periods coincide with the IQR of the latitude and longitude of the site. The line connecting the breeding ground with the stationary locations is the median position during the non-stationary periods together with the IQR (light-gray area). The hatched area shows the breeding range and the cross-hatched area shows the non-breeding range of the species (BirdLife International 2017) (Color figure online)

calibration equation from Procházka et al. (2013). More details are provided in ESM 1.

To estimate the origin of the feathers (moult location), we used the R package IsoriX version 0.4-1 (Courtiol et al. 2016). We calculated a spatial mixed model predicting a $\delta^{2} \mathrm{H}$ isoscape based on the measurements of the rainfall $\delta^{2} \mathrm{H}$ values by the Global Network of Isotopes in Precipitation (GNIP) corrected for altitudinal changes using the function 'Isofit' and 'Isoscape', respectively. We used all available precipitation data from August to October, when Paddyfield Warblers undergo a complete molt (Kennerley and Pearson 2010), and applied the transfer equation $\left(\delta^{2} \mathrm{H}_{\text {feather }}=1.28\right.$ $\left.\delta^{2} \mathrm{H}_{\text {isoscape }}-10.29\right)$ between the feather sample $\delta^{2} \mathrm{H}$ values and rainfall isoscape $\delta^{2} \mathrm{H}$ values of the closely related Eurasian Reed Warbler Acrocephalus scirpaceus from Procházka et al. (2013) using the function 'Calibfit'. Finally, 
we assigned the feather sample $\delta^{2} \mathrm{H}$ values using the function 'Isorix'. This function computes a map of $P$ values from an assignment test based on differences between $\delta^{2} \mathrm{H}$ values of interest and the predicted isotopic value at each location of the isoscape. As we found extensive variation in the $\delta^{2} \mathrm{H}$ values in our samples, we applied the clustering function 'pamk' from the R package fpc (Hennig 2015) to distinguish distinct groups of $\delta^{2} \mathrm{H}$ values which were then used for depicting the molting origins. For additional details see ESM 1. All analyses were conducted in R 3.3.1 ${ }^{\circledR}$ Core Team 2016).

\section{Results}

We recaptured one geolocator-tagged male in 2016. The bird left the breeding ground in the north-eastern direction on 15 August (median; interquartile range [IQR]: 15-16 August). The median post-breeding migration lasted 36 (IQR: 34-37) days during which the bird made five stopovers, varying in length from 1 to 11 days. The first three stopover sites were northeast of the breeding ground, while the last two stopover sites and the non-breeding site (mean arrival 20 September; IQR: 19-21 September) were to the southeast (Fig. 1). The total great circle distance between the breeding ground, the median estimates of the stopover sites and the non-breeding site was $5166 \mathrm{~km}$, whereas the direct great circle distance between the breeding and the estimated non-breeding site was only $4763 \mathrm{~km}$; the difference indicates a detour of approximately $7.8 \%$. We found a large $\delta^{2} \mathrm{H}$ variation among the 25 feather samples (mean: $-71.4 \pm 18.7 \% o ; n=25$ ) and identified seven clusters of feather $\delta^{2} \mathrm{H}$ values covering the entire non-breeding range of the species (Table 1; Fig. S1 in ESM 2). Stable isotope assignment of the feather molted during the light level recording was in agreement with the geolocator estimate of the non-breeding site (Fig. S2 in ESM 2).

Table 1 Mean $\delta^{2} \mathrm{H}$ values for the seven isotopic clusters and the number of samples belonging to each cluster

\begin{tabular}{lllr}
\hline Cluster & $\begin{array}{l}\text { Mean } \pm \text { standard } \\
\text { deviation }\end{array}$ & $\begin{array}{l}\text { Jaccard's similarity } \\
\text { index }\end{array}$ & $n$ \\
\hline 1 & $-98.7 \pm 2.8$ & 0.746 & 3 \\
2 & $-89.3 \pm 0.3$ & 0.448 & 2 \\
3 & $-81.8 \pm 1.3$ & 0.873 & 7 \\
4 & $-69.2 \pm 2.0$ & 0.790 & 4 \\
5 & $-59.4 \pm 2.2$ & 0.811 & 5 \\
6 & $-47.9 \pm 2.9$ & 0.567 & 2 \\
7 & $-33.6 \pm 4.4$ & 0.680 & 2 \\
All & $-71.4 \pm 18.7$ & - & 25 \\
\hline
\end{tabular}

\section{Discussion}

Our results support the previously suggested migration direction along the pathway of the recent range expansion in the Paddyfield Warbler (Zehtindjiev et al. 2010). Migration routes can reflect historical changes in the distribution of avian species (Bairlein et al. 2012). Our result is interesting as a number of other species show remarkable plasticity in migration directions or migration routes that have lead to the establishment of new non-breeding sites (Berthold et al. 1992). These inconsistent patterns suggest that avian species have different abilities to modify their migration routes in response to range expansions or environmental changes and that the propensity to alter migration behavior will largely depend on the ecology, genetic control of migration and evolutionary history of each species (Sutherland 1998). The time elapsed since the expansion may play an additional role. The degree of migratory connectivity can help to better understand ecology and demographic changes within a species. We have shown a low degree of connectivity in the Paddyfield Warbler, a pattern that seems to be frequent in long-distance migrants (Finch et al. 2017).

We are aware that our spatial assignment based on $\delta^{2} \mathrm{H}$ values may be affected by using multiple-year precipitation data for calculating the $\delta^{2} \mathrm{H}$ isoscape. However, the variation in $\delta^{2} \mathrm{H}$ values within our samples is expected to be independent of yearly variations in the underlying $\delta^{2} \mathrm{H}$ isoscape (see also Vander Zanden et al. 2014), and the agreement between the geolocator estimate and the stable isotope assignment provides additional support for our main conclusions (Fig. S2 in ESM 2). The question of whether our tracking data from a single individual represent the migration route and phenology of all Paddyfield Warblers from the Bulgarian population is clearly open to discussion. However, previous orientation experiments found similar results (Zehtindjiev et al. 2010; Ilieva et al. in review), suggesting that at least part of this population follows the same migration route.

Our findings on migration direction and notably the retracing of the recent range expansion as well as the weak migratory connectivity provides novel insights into the Paddyfield Warbler. However, many questions remain unanswered, and we hope that this study will stimulate future research on the migration and non-breeding distribution across populations and species that use the rarely studied Indo-European flyway.

Acknowledgements František Buben, Dimitar Dimitrov, Martin Marinov, Strahil Peev, Boris Prudík, Christoffer Sjöholm, Martin Sládeček, Matěj Žídek assisted in the field. Yvonne Klaar and Doris Fichte helped with the stable isotope analysis. We thank Adéla Stupková for the painting of the Paddyfield Warbler and her help in the field. We are grateful to anonymous reviewers for their comments on the manuscript. The study was funded by the Czech Science Foundation (project no. 13-06451S). The research was conducted under 
permissions 574/27.03.2014 and 672/17.03.2016 issued from the Ministry of Environment and Waters of Bulgaria and complies with the current Bulgarian laws.

\section{References}

Bairlein F, Norris DR, Nagel R, Bulte M, Voigt CC, Fox J, Hussell DJT, Schmaljohann H (2012) Cross-hemisphere migration of a 25 g songbird. Biol Lett 8:505-507. https://doi.org/10.1098/ rsbl.2011.1223

Berthold P, Helbig AJ, Mohr G, Querner U (1992) Rapid microevolution of migratory behaviour in a wild bird species. Nature 360:668-670. https://doi.org/10.1038/360668a0

BirdLife International (2017). Handbook of the birds of the World 2016. Bird species distribution maps of the world. Version 6.0. http://datazone.birdlife.org/species/requestdis. Accessed 15 Oct 2017

Courtiol A, Rousset F, Kramer-Schadt S (2016) R package Isorix: isoscape computation and inference of spatial origins using mixed models. R package version 0.4-1. GitHub. https://github.com/ courtiol/IsoriX_project/tree/master/IsoriX. Accessed 17 Oct 2017

Finch T, Butler SJ, Franco AMA, Cresswell W (2017) Low migratory connectivity is common in long-distance migrant birds. J Anim Ecol 86:662-673. https://doi.org/10.1111/1365-2656.12635

Gavrilenko MI (1954) Paddyfield warbler (Acrocephalus agricola septima subsp. nova) and reed warbler (Acrocephalus scirpaceus scirpaceus Herm.) in Poltavshchina: their biology distribution and taxonomy. Nauk Zap Poltavsk Ped Inst 7:53-62 (in Ukrainian)

Hennig C (2015) fpc: flexible procedures for clustering. R package version 2.1-10. https://CRAN.R-project.org/package $=$ fpc. Accessed 17 Oct 2017
Kennerley P, Pearson D (2010) Reed and bush warblers. A\&C Black Publishers Ltd, London

Popa-Lisseanu AG, Sörgel K, Luckner A, Wassenaar LI, Ibáñez C, Kramer-Schadt S, Ciechanowski M, Görföl T, Niermann I, Beuneux G, Mysłajek RW, Juste J, Fonderflick J, Kelm DH, Voigt CC (2012) A triple-isotope approach to predict the breeding origins of European bats. PLoS One 7:e30388. https://doi. org/10.1371/journal.pone.0030388

Procházka P, Van Wilgenburg SL, Neto JM, Yosef R, Hobson KA (2013) Using stable hydrogen isotopes $\left(\delta^{2} \mathrm{H}\right)$ and ring recoveries to trace natal origins in a Eurasian passerine with a migratory divide. J Avian Biol 44:541-550. https://doi.org/10.1111/j.1600048X.2013.00185.X

R Core Team (2016) R: A language and environment for statistical computing. R foundation for statistical computing, Vienna, Austria. https://www.R-project.org/. Accessed 17 Oct 2017

Rakhimberdiev E, Saveliev A, Piersma T, Karagicheva J (2017) FLightR: an R package for reconstructing animal paths from solar geolocation loggers. Methods Ecol Evol 8:1482-1487. https://doi. org/10.1111/2041-210X.12765

Sutherland W (1998) Evidence for flexibility and constraint in migration systems. J Avian Biol 29:441-446

Vander Zanden HB, Wunder MB, Hobson KA, Van Wilgenburg SL, Wassenaar LI, Welker JM, Bowen GJ (2014) Contrasting assignment of migratory organisms to geographic origins using longterm versus year-specific precipitation isotope maps. Methods Ecol Evol 5:891-900. https://doi.org/10.1111/2041-210X.12229

Zehtindjiev P, Ilieva M, Ảkesson S (2010) Autumn orientation behaviour of paddyfield warblers, Acrocephalus agricola, from a recently expanded breeding range on the western Black Sea coast. Behav Process 85:167-171. https://doi.org/10.1016/j.bepro c. 2010.07 .003

\section{Affiliations}

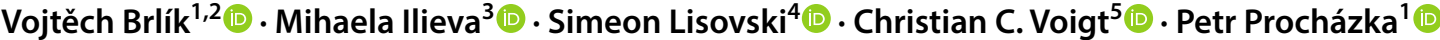

1 Institute of Vertebrate Biology, The Czech Academy of Sciences, Květná 8, 60365 Brno, Czech Republic

2 Department of Ecology, Faculty of Science, Charles University in Prague, Viničná 7, 12844 Prague 2, Czech Republic

3 Institute of Biodiversity and Ecosystem Research, Bulgarian Academy of Sciences, Gagarin Street 2, 1113 Sofia, Bulgaria
4 Swiss Ornithological Institute, Seerose 1, 6204 Sempach, Switzerland

5 Evolutionary Ecology Research Group, Leibniz Institute for Zoo and Wildlife Research, Alfred-Kowalke Straße 17, 10315 Berlin, Germany 